\title{
The Early Stages of Schizophrenia: Speculations on Pathogenesis, Pathophysiology, and Therapeutic Approaches
}

\author{
Jeffrey A. Lieberman, Diana Perkins, Aysenil Belger, Miranda Chakos, \\ Fred Jarskog, Kalina Boteva, and John Gilmore
}

Schizophrenia is commonly considered a neurodevelopmental disorder that is associated with significant morbidity; however, unlike other neurodevelopmental disorders, the symptoms of schizophrenia often do not manifest for decades. In most patients, the formal onset of schizophrenia is preceded by prodromal symptoms, including positive symptoms, mood symptoms, cognitive symptoms, and social withdrawal. The proximal events that trigger the formal onset of schizophrenia are not clear but may include developmental biological events and environmental interactions or stressors. Treatment with antipsychotic drugs clearly ameliorates psychotic symptoms, and maintenance therapy may prevent the occurrence of relapse. The use of atypical antipsychotic agents may additionally ameliorate the pathophysiology of schizophrenia and prevent disease progression. Moreover, if treated properly early in the course of illness, many patients can experience a significant remission of their symptoms and are capable of a high level of recovery following the initial episode. Because the clinical deterioration that occurs in schizophrenia may actually begin in the prepsychotic phase, early identification and intervention may favorably alter the course and outcome of schizophrenia. Biol Psychiatry 2001;50:884-897 (c) 2001 Society of Biological Psychiatry

Key Words: Schizophrenia, course, pathophysiology, early intervention

\section{Introduction}

S chizophrenia is widely considered to be a genetically mediated neurodevelopmental disorder. The neurodevelopmental theory of schizophrenia postulates that etio-

From the Department of Psychiatry, University of North Carolina School of Medicine, Chapel Hill, North Carolina.

Address reprint requests to Jeffrey A. Lieberman, M.D., Professor of Psychiatry, Pharmacology, and Radiology, University of North Carolina School of Medicine at Chapel Hill, Campus Box \#7160, 7025 Neurosciences Hospital, Chapel Hill NC 27599.

Received May 24, 2001; revised September 13, 2001; accepted September 24, 2001 logic and pathogenic factors occurring long before the formal onset of the illness (probably in gestation) disrupt the course of normal neural development, resulting in subtle alterations of specific neurons and circuits, which confer vulnerability and may ultimately lead to malfunction (Figure 1) (Bloom 1993; Lewis and Lieberman 2000; Murray and Lewis 1987; Weinberger 1987). The consequences of these neurodevelopmental aberrations, however, do not immediately cause clinical manifestations in schizophrenia as in other neurodevelopmental disorders, such as autism, fragile X, or Down's syndrome. Rather, symptoms typically present after a latency period of 1-3 decades. At the same time, high-risk and longitudinal birth cohort studies have identified social, motor, and cognitive dysfunctions and mild physical anomalies during childhood and adolescence, before the onset of illness (Jones 1997). These features, however, are mild in severity and have low predictive validity as individual markers of schizophrenia (Erlenmeyer-Kimling and Cornblatt 1987; Fish 1977).

\section{Clinical Course of Schizophrenia}

The onset of the formal symptoms of schizophrenia is generally preceded by a prodromal phase. So-called prodromal symptoms and behaviors (i.e., those that herald the approaching onset of the illness) include attenuated positive symptoms (i.e., illusions, ideas of reference, magical thinking, superstitiousness), mood symptoms (i.e., anxiety, dysphoria, irritability), cognitive symptoms (i.e., distractibility, concentration difficulties), social withdrawal, or obsessive behaviors to name a few (McGlashan 1996). Because many of these prodromal phenomena extensively overlap with the range of mental experiences and behaviors of persons in the ages of risk who do not subsequently develop schizophrenia, prodromal symptoms cannot be considered diagnostic. It is precisely their nonspecificity and lack of high predictive validity that limits their utility for the purposes of early intervention (Gottesman and Erlenmeyer-Kimling 2001; Schaffner and McGorry 2001). 


\section{Clinical and Pathophysiological Course of Schizophrenia}

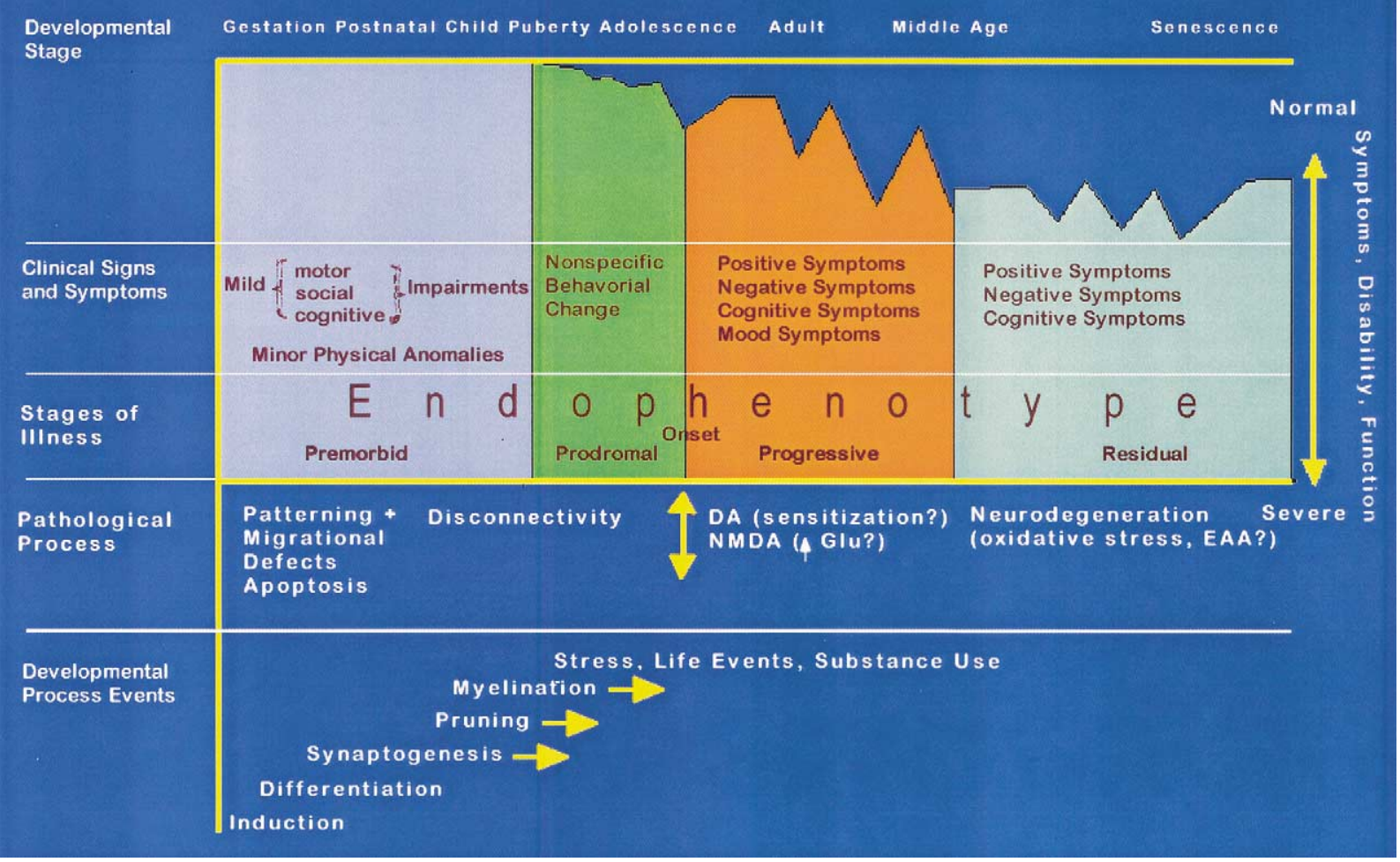

Figure 1. Clinical and pathophysiologic course of schizophrenia. This diagram attempts to integrate and schematically depict the clinical and pathophysiologic course of schizophrenia in its various clinical stages. To orient the reader starting from the top row: Developmental Stage describes the stage of life during which the various events and phenomena occur; Clinical Signs and Symptoms refers to the mental and behavioral manifestations of the illness; Stage of Illness describes all premorbid and morbid phases of the illness; Pathologic Process refers the hypothesized pathogenic and pathophysiologic mechanisms that underlie and are causal to the clinical manifestations of the disorder; Developmental Process and Events indicates the neurobiologic maturational processes and environmental events that may unmask or destabilize the neural circuits made vulnerable by etiologic and pathogenic factors. DA, dopamine; NMDA, N-methyl-D-aspartate; Glu, glutamate.

The development of frank psychotic symptoms marks the formal onset of first- episode schizophrenia, although this is usually not diagnosed for some time until the patient seeks or is brought to medical attention. Indeed, the duration of psychotic symptoms before diagnosis and treatment averages about 1 year, and if time from first appearance of prodromal symptoms is considered the average duration is about 3 years (McGlashan 1996). Despite this, most individuals recover symptomatically from the first episode; however, the majority of patients proceed to have one or more subsequent episodes in the form of psychotic relapses from which some proportion fail to recover, at least to the same degree as they had during their first or prior episode (Lieberman et al 1993, 1996; Robinson et al 1999b). This process of psychotic relapses, treatment failure, and incomplete recovery leads many patients to a chronic course of illness, and persistent disturbances and deficits in perceptions, thought processes, and cognition (Lieberman 1999; McGlashan 1988). In this way, patients accumulate morbidity in the form of residual or persistent symptoms and decrements in function from their premorbid status. The process of accruing morbidity in the context of exacerbations and (relative) remissions has been attributed to progression of the illness (Kraepelin 1919) and described as "clinical deterioration" (Bleuler 1980).

Interestingly, although the majority of patients with schizophrenia exhibit this pattern of deterioration, this occurs to different degrees and different temporal sequences in the illness. Despite this variation, the deterioration process predominantly occurs in the early phases of the illness-in the prepsychotic prodromal period and 
Table 1. Clinical and Pathologic Stages of Schizophrenia

\begin{tabular}{|c|c|c|c|c|}
\hline Illness stage & Developmental stage & Clinical features & Pathophysiological process & Treatment \\
\hline Premorbid & $\begin{array}{l}\text { Gestation, infancy, } \\
\text { childhood, early } \\
\text { adolescence }\end{array}$ & $\begin{array}{l}\text { Mild physical anomalies, } \\
\text { poor motor coordination, } \\
\text { mild cognitive } \\
\text { impairments, social } \\
\text { deficits }\end{array}$ & $\begin{array}{l}\text { Neurodevelopmental: } \\
\text { inductive, patterning, and } \\
\text { synaptogenetic anomalies }\end{array}$ & $\begin{array}{l}\text { None proven; } \\
\text { potential for gene } \\
\text { therapy }\end{array}$ \\
\hline Prodromal & $\begin{array}{l}\text { Adolescence and } \\
\text { early adulthood }\end{array}$ & $\begin{array}{l}\text { Nonspecific mood } \\
\text { symptoms: anxiety, } \\
\text { sadness, lability, } \\
\text { irritability; sleep } \\
\text { disturbances; cognitive } \\
\text { impairment in attention, } \\
\text { concentration; mild } \\
\text { psychotic symptoms: } \\
\text { illusions, suspiciousness, } \\
\text { magical thinking; } \\
\text { behavioral changes: } \\
\text { substance use, social } \\
\text { withdrawal, } \\
\text { preoccupations }\end{array}$ & $\begin{array}{l}\text { Maturational events } \\
\text { (postpubertal hormonal } \\
\text { effects, myelination, } \\
\text { synaptic regression) } \\
\text { interact with } \\
\text { developmental anomalies } \\
\text { to unmask vulnerabilities } \\
\text { to neuroplastic } \\
\text { dysfunction }\end{array}$ & $\begin{array}{l}\text { None proven; } \\
\text { potential for } \\
\text { supportive and } \\
\text { stress reduction } \\
\text { therapies, potential } \\
\text { use of GABA } \\
\text { agonists, NMDA } \\
\text { allosteric } \\
\text { modulators, } \\
\text { antioxidants, } \\
\text { atypical } \\
\text { antipsychotics }\end{array}$ \\
\hline Onset/deteriorative & $\begin{array}{l}\text { Adolescence and } \\
\text { early adulthood }\end{array}$ & $\begin{array}{l}\text { Psychosis, cognitive } \\
\text { impairment, negative } \\
\text { symptoms, and social } \\
\text { deficits }\end{array}$ & $\begin{array}{l}\text { Endogenous neurochemical } \\
\text { sensitization involving } \\
\text { meso-limbic-cortical- } \\
\text { striatal circuits mediated } \\
\text { by dopamine and } \\
\text { glutamate }\end{array}$ & $\begin{array}{l}\text { Antipsychotic drugs } \\
\text { proven efficacy; } \\
\text { potential use of } \\
\text { neuroprotective } \\
\text { agents }\end{array}$ \\
\hline Chronic/residual & $\begin{array}{l}\text { Adulthood, middle } \\
\text { age, senescence }\end{array}$ & $\begin{array}{l}\text { Negative symptoms, } \\
\text { cognitive impairment, } \\
\text { social deficits, and } \\
\text { psychosis }\end{array}$ & $\begin{array}{l}\text { Neuroprogression with } \\
\text { limited neurotoxicity, } \\
\text { loss of cell processes, } \\
\text { possible induction of } \\
\text { apoptosis of cortical- } \\
\text { limbic striatal neurons. }\end{array}$ & $\begin{array}{l}\text { Antipsychotics } \\
\text { proven but limited } \\
\text { efficacy; potential } \\
\text { for use of } \\
\text { experimental } \\
\text { agents as adjuncts }\end{array}$ \\
\hline
\end{tabular}

Table 1 describes the hypothesized pathologic stages of schizophrenia from a developmental, clinical, and pathophysiological perspective and the corresponding therapeutic strategies currently utilized or considered. The prodromal stage is transitional from the premorbid to the onset/deteriorative phase.

GABA, $\gamma$-aminobutyric acid; NMDA, N-methyl-D-aspartate.

during the first 5-10 years after the initial episode (Figure 1). Following this, the illness stabilizes and, although there may be subsequent exacerbations, there is no continued illness-driven decline in functioning and increase in residual symptoms (although the most severe variants may continue to decline through senescence [Harvey et al 1999]).

\section{Measures of Vulnerability and Pathophysiology}

Schizophrenia emerges over time, and the illness can be conceptualized as having three pathophysiologic stages, which correspond to distinct clinical stages: neurodevelopmental (premorbid) stage, neuroplastic (prodromal, onset, and deteriorative) stage, and neuroprogressive (deteriorative and chronic/residual) stage (Table 1) (Lieberman et al 1997).

\section{Measures of Vulnerability}

It is well established that having a first-degree relative with a psychotic disorder increases risk of developing schizophrenia and related psychotic disorders (Gottesman 1991). Prenatal or birth complications (i.e., hypoxia, infection, toxic exposure) also are associated with increased risk for schizophrenia (Buka and Fan 1999; Cannon et al 2000). Although specific genes and epigenetic factors (i.e., occurring during gestation and birth) are believed to confer vulnerability for the development of schizophrenia, there are no clear and specific manifestations by which at-risk persons can be identified. High-risk and longitudinal birth cohort studies have identified several premorbid factors that indicate increased risk for schizophrenia, including family history, prenatal and perinatal complications, body dysmorphias, and mild premorbid deficits in social, motor, and cognitive functions during childhood and adolescence (Jones 1997). For example, subtle motor abnormalities during infancy (Walker and Lewine 1990) and deficits in social functioning, organizational ability, and intellectual functioning at ages 16-17 years have been associated with the later appearance of schizophrenia (Davidson et al 1999). In addition, individuals with schizophrenia have subtle but measurable 
body dysmorphias, particularly of body structures that are derived from neural crest tissue and develop during the late first and second trimesters of fetal life (Maynard et al, 2001; Waddington et al 1999). All of these features, however, are mild in severity and have low predictive validity as individual markers.

Studies of individuals at risk for schizophrenia (such as first-degree relatives and individuals with schizotypal personality disorders) and first-episode patients have found that information processing deficits are one of the earliest clinical and cognitive markers of vulnerability for schizophrenia (Carter et al 1997; Nuechterlein and Dawson 1984; Nuechterlein et al, 1991, 1994; Pert et al 1992; Posner 1988; Weiss et al 1992). Attention deficits are present before the onset of the illness, and the clinical expression of the illness in high-risk adolescents (Cornblatt and Keilp 1994). Executive function impairments, including working memory, are also consistently demonstrated in patients with schizophrenia, as well as those with schizophrenia-spectrum disorders (Goldberg and Gold 1995). Although attention and executive function deficits have been associated with prefrontal cortical pathology in schizophrenia, other information processing deficits suggest a significant breakdown in hippocampal and temporal cortical functions.

Neurophysiologic studies of patients with schizophrenia have revealed abnormal auditory information selection processes during oddball tasks. These deficits have been found as early as the initial sensory processing stage of information, and suggest that sensory gating and attention deficits are core components of the pathophysiology of schizophrenia (Adler et al 1982; Boutros and Belger 1999). The observation of decreased P50 suppression in over half of the first-degree relatives of schizophrenic patients (Siegel et al 1984) suggests that P50 may be a vulnerability marker for schizophrenia and schizotypal personality disorder (Cadenhead et al 2000; Clementz et al 1998; Siegel et al 1984; Waldo et al 1991).

Recently, in utero ultrasonography was used to examine the brain structure in high-risk fetuses and showed that high-risk fetuses exhibited enlarged lateral ventricles compared with matched normal fetuses (Gilmore et al 2000). This evidence suggests that a genetic developmental diathesis of vulnerability for schizophrenia manifest in brain morphology is present long before the onset of symptoms and is reflected by characteristic features that are neither severe nor always specific.

\section{Neuropathology of Schizophrenia}

The proximal events that trigger the formal onset of schizophrenia are not known but may include normal neurobiologic maturational processes (i.e., experiencedependent axonal and dendritic proliferation, programmed cell death, axonal myelination, synaptic pruning) and environmental interactions, including gestational insults, trauma, stress, and substance abuse. This suggests the possibility that schizophrenia is unmasked or provoked by developmental biological events and/or environmental perturbations (Lieberman et al 1997; Weinberger 1987).

Evidence for a progressive, as well as a developmental, component to the illness is derived from recent neuroimaging studies in first-episode patients. These studies have found evidence of neuroanatomical changes at first treatment contact, as well as evidence of limited neuroanatomical progression. Comparisons of studies evaluating chronic patients with the few available studies of recent onset or first-episode patients with schizophrenia have revealed somewhat greater rates of morphologic abnormalities (reflected in the number of regions affected and the size of volume differences) in older and chronic patients (Bogerts et al 1993; Lieberman et al 1992).

Progression of neuropathology is suggested by the cross-sectional brain imaging studies that show that chronically ill schizophrenic patients have more numerous and severe structural brain abnormalities compared with firstepisode patients; however, prospective imaging studies provide the most direct test of whether there is progression or stasis of brain abnormalities in schizophrenic patients. Three prospective studies of first-episode patients (DeLisi et al 1992, 1995, 1997; Gur et al 1998; Lieberman et al 1996, 2001) and five prospective studies of chronic patients (Davis et al 1998; Garver et al 1997; Gur et al 1998; Mathalon et al 2001; Rapoport et al 1999) have examined the progression of structural brain abnormalities and/or the relationship of progression to clinical course in patients with schizophrenia. These studies have produced mixed findings, but generally suggest that a subset of patients with poor treatment outcome or a more severe course are more likely to show progressive changes in brain morphology, with ventricular enlargement and cortical gray matter volume reductions as the most consistent findings. Some investigators have also found a negative correlation between patient compliance with antipsychotic medications and morphologic changes, suggesting that use of antipsychotics may slow disease progression in some patients (DeLisi et al 1992, 1995, 1997; Lieberman et al 2001; Nair et al 1997). There is also convincing evidence that patients with treatment-refractory childhood onset and geriatric schizophrenic patients have progressive ventricular enlargement (Davis et al 1998; Rappaport et al 1999).

Proton magnetic resonance spectroscopy $\left({ }^{1} \mathrm{H}\right.$ MRS) is used to measure compounds such as $\mathrm{N}$-acetylaspartate (NAA), which is a neuronal marker that reflects cell number and density (Stanley et al 1995b). Most ${ }^{1} \mathrm{H}$ MRS 
studies, as well as postmortem studies, of patients with schizophrenia have shown reductions in NAA in either the frontal or temporal lobes (Akbarian et al 1993a, 1993; Bertolino et al 1996b; Buckley et al 1994; Choe et al 1994; Fukuzako et al 1995; Maier et al 1995; Nasrallah et al 1994; Renshaw et al 1995; Shioiri et al 1996; YurgelunTodd et al 1996), with some exceptions (Bartha et al 1997; Stanley et al 1996).

There is increasing evidence that NAA is a metabolically active metabolite that is influenced by pharmacologic treatment as well as disease state (Vion-Dury et al 1995). Bertolino et al (1996a) reported a highly significant effect of antipsychotic treatment in increasing the concentration of NAA in the dorsolateral prefrontal cortex (DLPFC) of patients with schizophrenia. Antipsychotic medications affect the concentration and activity of glutamate in the prefrontal cortex (Stanley et al 1996). Therefore, increases in NAA in the DLPFC associated with antipsychotic treatment may be mediated by increases in glutamate in this region.

Using ${ }^{1} \mathrm{H}$ MRS and ${ }^{31} \mathrm{P}$ MRS, investigators have found that patients with schizophrenia exhibit differences in the concentrations of NAA and various phosphomonoester (PME) and phosphodiester (PDE) moieties in specific brain regions, including the temporal and prefrontal cortex. $\mathrm{N}$-acetylaspartate is an abundant amino acid located in neuronal cell bodies and processes. The PMEs are phospholipids involved in membrane synthesis, and PDEs are byproducts of lipid metabolism that are believed to reflect membrane turnover. Thus, these biochemical measures can be used to indirectly assess neuronal and glial mass, integrity, and turnover, which may reflect pathophysiologic processes. Investigators have found that NAA is consistently reduced in the temporal cortex in patients with schizophrenia (including first-episode patients), but less consistently so in other brain regions, notably the prefrontal cortex (Keshavan et al 2000). There have been no reports of longitudinal ${ }^{1} \mathrm{H}$ MRS studies of NAA.

${ }^{31} \mathrm{P}$ MRS studies of first-episode patients have described reduced concentrations of PMEs and elevated levels of PDEs primarily in the prefrontal cortex, suggesting increased phospholipid metabolism, possibly due to membrane turnover in response to a pathologic process, such as excessive synaptic pruning (Keshavan et al 1994; Pettegrew et al 1991; Stanley et al 1995b). Stanley et al (1995a) found that PMEs were generally lower in patients with schizophrenia at all stages of the illness, but PDEs were elevated in first-episode patients, perhaps reflecting a more fulminant process during that stage.

In another study of patients with schizophrenia in various stages of illness, Stanley and coworkers, using ${ }^{1} \mathrm{H}$ MRS, found higher glutamine concentrations in patients with schizophrenia compared with controls (Stanley et al
1996). In addition, glutamine concentrations were positively correlated with illness duration, and this relationship was not associated with the effects of age or treatment. Moreover, glutamine levels were reduced by antipsychotic drug treatment. The role of the excitatory amino acids (EAA), glutamate and aspartate, have been studied in detail in various preparations and animal models of neurodegeneration (Lieberman 1999). It has been proposed that the glutamate may induce slow excitotoxic effects that in turn induce the loss of cell processes, possibly through apoptosis in a manner that would not induce reactive gliosis (Jarskog et al 2000; Lieberman 1999b; Wang et al 1999). Abnormally elevated glutamine levels, therefore, may be associated with schizophrenia and disease progression.

Several investigators have described pathophysiologic processes that involve or could lead to neurodegeneration. These specifically implicate N-methyl-D-aspartate (NMDA) receptor hypofunction and excitotoxicity (Olney and Farber 1995), antagonism of NMDA receptors by $\mathrm{N}$-acetylaspartylglutamate (NAAG) and consequent oxidative stress (Coyle and Puttfarcken 1993), reduction in $\gamma$-aminobutyric acid (GABA) interneuron-mediated inhibition of pyramidal neurons in the cingulate cortex (Benes 1995), and dopamine-mediated neurochemical sensitization (Laruelle et al 1999; Lieberman et al 1997) and neurotoxicity (Wyatt 1995) as pathogenic mechanisms (Table 1).

\section{Treatment Strategies to Alter Course and Prevent Progression of Schizophrenia}

Some authors have suggested that pharmacologic treatment suppresses the symptoms of schizophrenia but does not alter the course or potential progression of the disease (Hegarty et al 1994). In contrast, others have postulated that antipsychotic drugs ameliorate the pathophysiologic process that causes psychotic symptoms and leads to clinical deterioration (Jody et al 1990; Lieberman et al 1997; Wyatt 1991). Some of the most important evidence for the latter hypothesis is derived from treatment studies of first-episode patients and has shown associations between the duration of pretreatment psychosis and outcome (see references in Table 2).

Specifically, many, but not all, of these studies found that longer periods of active psychotic symptoms before first treatment were associated with worsened outcome. What is remarkable is that this relationship was present for outcomes measured in multiple ways, including the time to or level of recovery from the first episode, the time to or likelihood of relapsing after recovery from the first episode, and long-term outcomes measured globally for up to 5 years after beginning treatment for first-episode schizo- 
Table 2. Duration of Untreated Psychosis and Outcome in First-Episode Schizophrenia

\begin{tabular}{|c|c|c|c|}
\hline Reference & Study sample & Duration of illness & Duration of illness and outcome \\
\hline Waddington et al 1995 & $\begin{array}{l}\text { DUP has been regarded as a } \\
\text { continuous variable in a } \\
\text { multiple regression } \\
\text { analysis in } 88 \text { subjects }\end{array}$ & $\begin{array}{l}\text { DUP: mean } 17.1 \mathrm{y}, \text { range } 0-51 \\
\text { Duration of illness: mean } \\
34.6 \mathrm{y}, \mathrm{SD}=11.5\end{array}$ & $\begin{array}{l}\text { Longer DUP predicts more severe } \\
\text { negative symptoms and general } \\
\text { cognitive impairment at follow- } \\
\text { up }\end{array}$ \\
\hline
\end{tabular}

Scully et al 1997

Jablensky et al 1992

Loebel et al 1992

Robinson et al 1999a

Robinson et al $1999 \mathrm{~b}$

Szymansky et al 1996
$78.2 \%$ of the 1379 initially examined patients completed 2-year followup and were included in the analysis of course and outcome

\section{$n=118$ dichotomized to long (more than 1 year) and short (less than $1 \mathrm{y}$ ) DUP groups}

$n=104$

Not reported

DUP: mean 51.9 wks, SD = 82.3 Duration of untreated illness: mean 150.8 wks, SD $=176.6$ Duration of prodrome: Mean $=98.5$ wks, SD $=156.6$

DUP: mean $71 \mathrm{wks}, \mathrm{SD}=150$

Duration of untreated illness: mean 143 wks, SD $=205$

DUP: mean 64 wks, SD $=146$

Duration of untreated illness: mean 119 wks, SD $=181$

DUP of the 34 first-episode patients: Mean $3.2 \mathrm{y}, \mathrm{SD}=$ 4.3
Longer DUP predicts more severe negative symptoms and general cognitive impairment at followup, DUP is not associated with level of positive symptoms and executive dysfunction at followup

Type of onset is a significant predictor of a 2-year pattern of course, $\%$ time spent in psychotic episodes, \% time spent in complete remission, $\%$ time spent in unimpaired social functioning, and \% time on antipsychotic medication. Patients with acute onset had the most favourable outcomes, patients with gradual onset had the least favourable outcomes, those with subacute onset were in the middle

Long DUP is associated with longer time to remission and lower level of remission after first psychotic break

DUP is associated with treatment response at a level of significance $p=.03$

DUP of $1 \mathrm{y}$ or longer does not predict first relapse

Longer duration of untreated psychosis correlates with less improvement of positive symptoms in the first 6 mos of neuroleptic treatment 
Table 2. (Continued)

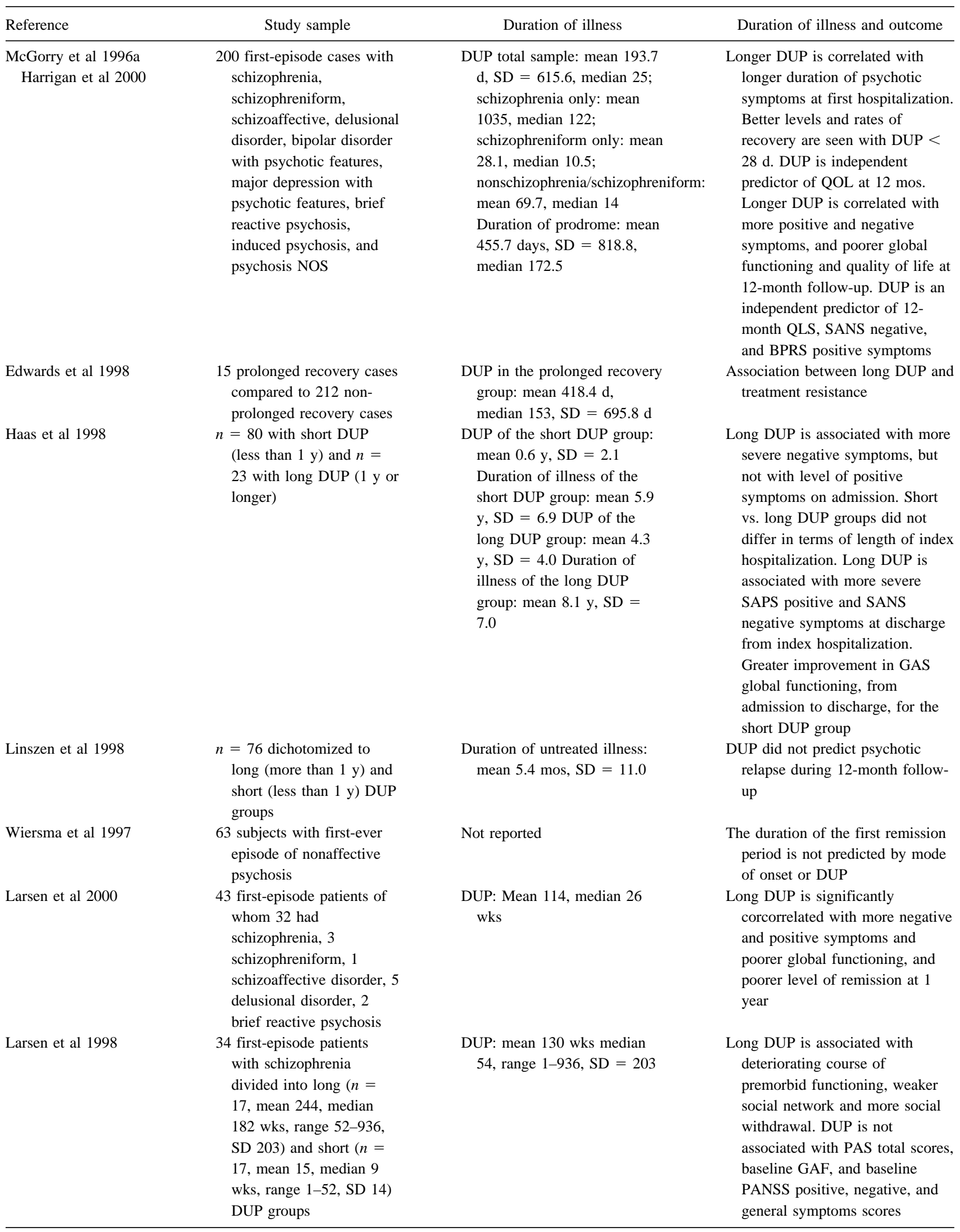


Table 2. (Continued)

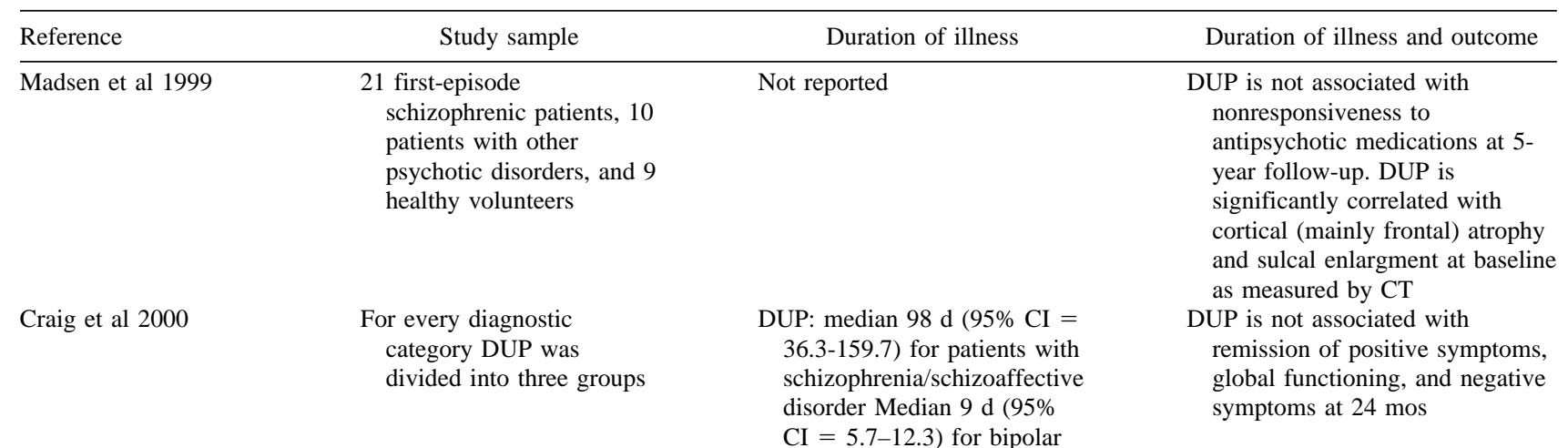

Hoff et al 2000

Ho et al 2000

Barnes et al 2000

Drake et al 2000

Whooley et al 1997

Bottlender et al 2001 (personal communication)
50 subjects divided into short $(n=15)$ and long $(n=35)$ DUP groups with $1 \mathrm{y}$ as the cutoff point

74 subjects, DUP is treated as a continuous variable

53 subjects split around the median of 26 wks into short and long DUP groups

.3) for bipolar disorder Median 22 d (95\% $\mathrm{CI}=6.6-37.4)$ for psychotic depression

DUP: mean 11.4 mos, SD = 16.2, range 1-72 Duration of behavioral change: mean 3.4 $\mathrm{y}, \mathrm{SD}=6.1$, range $<1-41$

DUP: mean 60.8 wks, median 13.5 SD $=130.5$ Duration of untreated illness: mean 130.5 wks, $\mathrm{SD}=204.5$, median 53.5

DUP: mean 59 wks, median $26, \mathrm{SD}=93$ Duration of prodrome: mean 113.5 wks, $\mathrm{SD}=232$

DUP: mean 38 wks, median 12 , range 4-624 16 patients had DUP between 2 and $16 \mathrm{y}$

subjects, DUP regarded as a continuous variable

53 subjects dichotomized into short-term symptom (DUP less than $1 \mathrm{y}, n=$ 30) and long-term symptom (DUP group of 1 y or longer, $n=23$ ) groups. Patient's report was used for estimating DUP

58 subjects, DUP is categorized in three groups: $\leq 6 \operatorname{mos}(n=$ $39) ;>6$ mos and $\leq 1$ y $(n$ $=5)$; and $>1$ y $(n=14)$
DUP per patient report: mean 22.7 mos, median $6, \mathrm{SD}=$ 36.8 , range 1-240 DUP per family report: mean 15.9 mos, median $3, \mathrm{SD}=34.5$, range $0-240$

DUP is less than 6 mos in 39 patients $(67 \%)$, between 6 mos and $1 \mathrm{y}$ in 5 patients $(8.6 \%)$, and more than $1 \mathrm{y}$ in 14 patients $(24.1 \%)$
No association between DUP and baseline MRI brain structure volumetric measurements or neuropsychologic summary scores

DUP is not associated with time to positive symptom remission. DUP is not significantly correlated with quality of life or the severity of negative, psychotic, and disorganized symptoms at 6-month follow-up

No difference between the short and long DUP groups on measures of IQ or intellectual decline from premorbid level, oculomotor and neurocognitive function, psychomotor poverty, reality distortion, and disorganization syndrome scores at baseline. DUP is not associated with response to first exposure to antipsychotic medication as measured by the Brenner scale (Brenner et al 1990)

Longer DUP was correlated with more positive and general PANSS symptoms, but not with more negative symptoms at baseline. Longer DUP predicts less improvement of PANSS during 6-12 wks of treatment DUP is not associated with PANSS total and syndrome scores, but long DUP predicts significantly poorer quality of life at baseline evaluation

Longer DUP is associated with more pronounced negative, positive, and general psychopathological symptoms as well as lower global functioning $15 \mathrm{y}$ after first hospitalization 
Table 2. (Continued)

\begin{tabular}{|c|c|c|c|}
\hline Reference & Study sample & Duration of illness & Duration of illness and outcome \\
\hline Black et al 2001 & $\begin{array}{l}19 \text { subjects categorized into } \\
\text { short }(n=9) \text { and long ( } n \\
=10) \text { DUP groups split } \\
\text { around the median DUP } \\
\text { of } 57 \text { wks }\end{array}$ & $\begin{array}{l}\text { DUP total sample: median } 57 \\
\text { wks Mean short DUP group } \\
11.28 \text { wks, Median } 8.14 \\
\text { Mean long DUP group } 147.8 \\
\text { wks, median } 116.6\end{array}$ & $\begin{array}{l}\text { Long DUP is associated with more } \\
\text { severe PANSS negative } \\
\text { symptoms. DUP is not } \\
\text { associated with PANSS positive } \\
\text { or total PANSS ratings. Long } \\
\text { DUP is associated with more } \\
\text { severe positive symptoms and } \\
\text { poorer global functioning at 6- } \\
\text { month follow-up }\end{array}$ \\
\hline Verdoux et al 2001 & $\begin{array}{l}65 \text { subjects divided into } \\
\text { short }(<3 \text { mos) and long } \\
(\geq 3 \text { mos }) \text { DUP groups }\end{array}$ & $\begin{array}{l}\text { DUP: mean } 22.7 \text { mos, median } \\
\quad 3, \mathrm{SD}=59.3\end{array}$ & $\begin{array}{l}\text { Subjects with long DUP are more } \\
\text { likely to present with psychotic } \\
\text { symptoms and continuous illness } \\
\text { course over the 2-year follow up } \\
\text { period }\end{array}$ \\
\hline
\end{tabular}

DUP, duration of untreated psychosis; NOS, not otherwise specified; QOL, quality of life; QLS, quality of life scale; SANS, scale for the assessment of negative symptoms; BPRS, Brief Psychiatric Rating Scale; SAPS, scale for the assessment of positive symptoms; GAS, global assessment scale; PANSS, positive and negative syndrome scale; CT, computed tomography; MRI, magnetic resonance imaging.

phrenia. Moreover, maintenance treatment studies have demonstrated the prophylactic effect of antipsychotic drugs in preventing relapse. Treatment may be responsible for mitigating the course of illness and producing more favorable outcomes (Davis and Andriukaitis 1986). With the advent of the second generation or atypical drugs, the question is asked whether they have any selectively beneficial effects that would improve outcome if used in first episode patients (Lieberman et al 1996). Preclinical studies suggest that antipsychotic drugs may do more than just suppress symptoms and ameliorate the underlying pathophysiology, forestall disease progression, and prevent morbidity from increasing (Mohn et al 1999; Olney and Farber 1995; Duncan et al 2000). Such a hypothesized effect could be achieved in a variety of ways. On a clinical level these drugs have superior efficacy in their rapidity and degree of symptom remission and prevention of relapse. Because they are better tolerated they should have higher rates of treatment adherence, which should result in fewer relapses. At a biologic level atypical drugs may be more effective at alleviating the pathophysiology of schizophrenia and may have a more efficient and effective mechanism of action. Preclinical studies suggest a possible basis for this hypothesized effect (Mohn et al 1999; Olney and Farber 1995; Duncan et al 2000). Based on the glutamate/NMDA receptor hypofunction model of schizophrenia, the ability of antipsychotic drugs to alter glutamate-mediated behavioral and cellular functions induced by NMDA antagonists have been examined. These studies show that conventional drugs can alleviate only some of the behavioral effects of NMDA antagonists (i.e., increased locomotor activity but not social isolation and acoustic startle responses) but that they do not block the cellular effects reflected by early immediate gene expression and uptake of 2-deoxyglucose, a marker of cellular metabolism. Moreover, studies with an NMDA knock- down mouse strain that only partially expresses the NR1 subunit of the NMDA receptor have demonstrated that the atypical drug clozapine blocks the abnormal behaviors (i.e., increased locomotor activity) at 1/40 the dose of haloperidol (Mohn et al 1999). Several clinical studies have also begun to examine this question. Preliminary reports from these suggest that there may be advantages in the use of atypical drugs that would lead to better long-term outcomes (Emsley 1999; McEvoy et al 2000).

The theory that schizophrenia is a genetically mediated, neurodevelopmental disorder suggested that affected individuals were "doomed from the womb" and consequently was pessimistic as to prognosis; however, recent studies have shown that most patients experience a substantial reduction and even remission of psychotic symptoms following the initial episode if treated properly early in the course of their illness, although associated negative and cognitive symptoms can persist (Whitesides et al 1998). These studies also revealed that individuals suffering first-episode psychosis experienced an alarming delay between onset of psychotic symptoms and initiation of treatment that averaged between 1 and 2 years (Table 2) (McGlashan 1999).

If the pathophysiology of schizophrenia is progressive, beginning at or before the onset of psychosis, then the potential for prompt or even early intervention would seem very compelling. Thus, the prospect that early intervention favorably alters the course and outcome of schizophrenia has exerted a powerful influence on psychiatric research and treatment strategies. If recovery and improved outcomes occur with earlier treatment that reduces the duration of active psychosis, then it is logical to try to intervene before the onset of illness. For this reason, the prodromal stage of schizophrenia has become a prime target for research and development of therapeutic strategies (McGlashan 1996; McGorry et al 1999). 
The prodromal stage is believed to be a critical juncture in the course of schizophrenia because, not only does it herald the onset of psychosis and the manifestations by which the illness is diagnosed (and then treated), but because the clinical deterioration that occurs in the early stages of the illness may actually begin in the prepsychotic phase (Carpenter et al 1991; Hafner et al 1998). Indeed, the momentum toward early effective treatment intervention is so great that outreach programs for early identification and psychosis prevention services are now being developed and evaluated worldwide (McGlashan 1996).

Although overall, this represents a substantial advance in the attitude and approach to the clinical care of patients with schizophrenia, this movement has stimulated many questions and controversies (Lieberman and Fenton 2000). Among these is the feasibility and safety of early intervention, particularly with pharmacologic agents, before the establishment of a clear diagnosis. The effectiveness of such potentially powerful preventive strategies is dependent on the soundness of the methods, the certainty with which persons truly at risk for imminent illness can be identified, and understanding of the potential risks and benefits of careful watching versus preemptive treatment. There is a critical need for a better understanding of the natural history of the early stages of schizophrenia and how patients progress from the prodromal stage to the onset of psychosis.

\section{Conclusions}

There has been remarkably little study of the earliest stages of schizophrenia and the reasons why the duration of active first-episode psychosis is so prolonged. For example, the actual nature and time-course by which patients develop symptoms is largely unknown. Moreover, whether the mode and nature of the onset differs by gender, age of onset, or in relation to premorbid characteristics (i.e., intelligence quotient). Regarding treatment, it is not known how much of the duration of active psychosis is accounted for by delay in patients seeking treatment and how much is because of delay in establishment of diagnosis and initiation of treatment. If it is the former, then the question is whether this is associated with lack of disease awareness and recognition among patients, families, and friends. If the latter, then the question must be asked whether patients have ready access to mental healthcare. This is a public health problem of some magnitude. It is not clear how knowledge, skills, attitudes, beliefs, and barriers operate as determinants of helpseeking in individuals experiencing symptoms or in persons who notice symptoms in family members, friends, or acquaintances, and how these factors can be modified. Clearly, delay in seeking treatment by symptomatic pa- tients potentially may be reduced by various measures, including development of community outreach programs and increasing public awareness of mental illness. Strategies, such as the integration of early detection teams into youth services in Australia (McGorry et al 1996b) and sustained antistigma-oriented social marketing in Norway (McGlashan 1996), are important pilot tests of innovative models to meet this challenge.

Historically, schizophrenia has been regarded with therapeutic pessimism; however, demonstration of good treatment outcomes in first-episode and recent-onset patients and the association between duration and episodes of active psychosis with progression and outcome of the disorder has generated efforts and hope that morbidity may be limited and the course of illness altered by early intervention. The advent of atypical antipsychotic drugs may be a consequential factor in this evolving therapeutic strategy, because their improved safety and efficacy profile compared with standard neuroleptics increases the likelihood that patients will adhere to treatment and potentially experience improved therapeutic effects. In addition, preliminary evidence suggests that atypical antipsychotics may have undefined properties that will more efficiently ameliorate the pathophysiology of schizophrenia associated with psychosis and thereby prevent disease progression; however, future studies of the onset of schizophrenia and advances in drug discovery may lead to new even more effective intervention and prevention strategies.

This work was supported by the University of North Carolina Mental Health and Neuroscience Clinical Research Center (MH 33127) and a National Institute of Mental Health Research Scientist Development Award (MH 00537) to Dr. Lieberman and the Foundation of Hope of Raleigh North Carolina.

Aspects of this work were presented at the conference, "New Perspectives on the Neurobiology of Schizophrenia and the Role of Atypical Antipsychotics," held November 10-12, 2000, in Key West, Florida. The conference was sponsored by the Society of Biological Psychiatry through an unrestricted educational grant provided by AstraZeneca.

\section{References}

Adler LE, Pachtman E, Franks RD, Pecevich M, Waldo MC, Freedman R (1982): Neurophysiological evidence for a defect in neuronal mechanisms involved in sensory gating in schizophrenia. Biol Psychiatry 17:639-654.

Akbarian S, Bunney WE Jr, Potkin SG, Wigal SB, Hagman JO, Sandman CA, et al (1993): Altered distribution of nicotinamide-adenine dinucleotide phosphate- diaphorase cells in frontal lobe of schizophrenics implies disturbances of cortical development. Arch Gen Psychiatry 50:169-177.

Akbarian S, Vinuela A, Kim JJ, Potkin SG, Bunney WE Jr, Jones EG (1993): Distorted distribution of nicotinamide-adenine 
dinucleotide phosphate- diaphorase neurons in temporal lobe of schizophrenics implies anomalous cortical development. Arch Gen Psychiatry 50:178-187.

Barnes TR, Hutton SB, Chapman MJ, Mutsatsa S, Puri BK, Joyce EM (2000): London first-episode study of schizophrenia. Am J Psychiatry 153:519-525.

Bartha R, Williamson PC, Drost DJ, Malla A, Carr TJ, Cortese L, et al (1997): Measurement of glutamate and glutamine in the medial prefrontal cortex of never-treated schizophrenic patients and healthy controls by proton magnetic resonance spectroscopy. Arch Gen Psychiatry 54:959-965.

Benes FM (1995): Is there a neuroanatomic basis for schizophrenia? An old question revisited. The Neuroscientist 1:104115.

Bertolino A, Nawroz S, Mattay VS, Barnett AS, Duyn JH, Moonen CT, et al (1996a): Regionally specific pattern of neurochemical pathology in schizophrenia as assessed by multislice proton magnetic resonance spectroscopic imaging. Am J Psychiatry 153:1554-1563.

Bertolino A, Nawroz S, Mattay VS, Barnett AS, Duyn JH, Moonen CT, et al (1996b): Regionally specific pattern of neurochemical pathology in schizophrenia as assessed by multislice proton magnetic resonance spectroscopic imaging. Am J Psychiatry 153:1554-1563.

Black K, Peters L, Rui Q, Milliken H, Whitehorn D, Kopala LC (2001): Duration of untreated psychosis predicts treatment outcome in an early psychosis program. Schizophr Res 47:215-222.

Bleuler M (1980): [Schizophrenia-neurosis]. Dtsch Med Wochenschr 105:209-212.

Bloom FE (1993): Advancing a neurodevelopmental origin for schizophrenia. Arch Gen Psychiatry 50:224-227.

Bogerts B, Lieberman JA, Ashtari M, Bilder RM, Degreef G, Lerner G, et al (1993): Hippocampus-amygdala volumes and psychopathology in chronic schizophrenia. Biol Psychiatry 33:236-246.

Bottlender R, Rudolf D, Strauss A, Moller HJ (2001): Moodstabilisers reduce the risk of developing antidepressant-induced maniform states in acute treatment of bipolar I depressed patients. J Affect Disord 63:79-83.

Boutros NN, Belger A (1999): Midlatency evoked potentials attenuation and augmentation reflect different aspects of sensory gating. Biol Psychiatry 45:917-922.

Brenner HD, Dencker SJ, Goldstein MJ, Hubbard JW, Keegan DL, Kruger G, Kulhanek F, Liberman RP, Malm U, Midha KK (1990): Defining treatment refractoriness in schizophrenia. Schizophr Bul 16:551-561.

Buckley P, Thompson PA, Way L, Meltzer HY (1994): Substance abuse and clozapine treatment. J Clin Psychiatry 55(suppl B):114-116.

Buka SL, Fan AP (1999): Association of prenatal and perinatal complications with subsequent bipolar disorder and schizophrenia. Schizophr Res 39:113-119.

Cadenhead KS, Light GA, Geyer MA, Braff DL (2000): Sensory gating deficits assessed by the P50 event-related potential in subjects with schizotypal personality disorder. Am J Psychiatry 157:55-59.

Cannon TD, Rosso IM, Hollister JM, Bearden CE, Sanchez LE, Hadley T (2000): A prospective cohort study of genetic and perinatal influences in the etiology of schizophrenia. Schizophr Bull 26:351-366.

Carpenter WT Jr, Buchanan RW, Breier A, Kirkpatrick B, Thaker G, Tamminga C (1991): Psychopathology and the question of neurodevelopmental or neurodegenerative disorder. Schizophr Res 5:192-194.

Carter CS, Mintun M, Nichols T, Cohen JD (1997): Anterior cingulate gyrus dysfunction and selective attention deficits in schizophrenia: [15O]H2O PET study during single-trial Stroop task performance [see comments]. Am J Psychiatry 154:1670-1675.

Choe BY, Kim KT, Suh TS, Lee C, Paik IH, Bahk YW, et al (1994): 1H magnetic resonance spectroscopy characterization of neuronal dysfunction in drug-naive, chronic schizophrenia. Acad Radiol 1:211-216.

Clementz BA, Geyer MA, Braff DL (1998): Poor P50 suppression among schizophrenia patients and their first- degree biological relatives. Am J Psychiatry 155:1691-1694.

Cornblatt BA, Keilp JG (1994): Impaired attention, genetics, and the pathophysiology of schizophrenia. Schizophr Bull 20:3146.

Coyle JT, Puttfarcken P (1993): Oxidative stress, glutamate, and neurodegenerative disorders. Science 262:689-695.

Craig TJ, Bromet EJ, Fennig S, Tanenberg-Karant M, Lavelle J, Galambos N (2000): Is there an association between duration of untreated psychosis and 24-month clinical outcome in a first-admission series? Am J Psychiatry 157:60-66.

Davidson M, Reichenberg A, Rabinowitz J, Weiser M, Kaplan Z, Mark M (1999): Behavioral and intellectual markers for schizophrenia in apparently healthy male adolescents. Am J Psychiatry 156:1328-1335.

Davis JM, Andriukaitis S (1986): The natural course of schizophrenia and effective maintenance drug treatment. J Clin Psychopharmacol 6:2S-10S.

Davis KL, Buchsbaum MS, Shihabuddin L, Spiegel-Cohen J, Metzger M, Frecska E, et al (1998): Ventricular enlargement in poor-outcome schizophrenia [see comments]. Biol Psychiatry 43:783-793.

DeLisi LE, Sakuma M, Tew W, Kushner M, Hoff AL, Grimson R (1997): Schizophrenia as a chronic active brain process: A study of progressive brain structural change subsequent to the onset of schizophrenia [see comments]. Psychiatry Res 74: 129-140.

DeLisi LE, Stritzke P, Riordan H, Holan V, Boccio A, Kushner M, et al (1992): The timing of brain morphological changes in schizophrenia and their relationship to clinical outcome. Biol Psychiatry 31:241-254.

DeLisi LE, Tew W, Xie S, Hoff AL, Sakuma M, Kushner M, et al (1995): A prospective follow-up study of brain morphology and cognition in first-episode schizophrenic patients: Preliminary findings. Biol Psychiatry 38:349-360.

Drake RJ, Haley CJ, Akhtar S, Lewis SW (2000): Causes and consequences of duration of untreated psychosis in schizophrenia. Br J Psychiatry 177:511-515.

Duncan GE, Miyamoto S, Leipzig JN, Lieberman JA (2000): Comparison of the effects of clozapine, risperidone, and olanzapine on ketamine-induced alterations in regional brain metabolism. J Pharmacol Exp Ther 293:8-14.

Edwards J, Maude D, McGorry PD, Harrigan SM, Cocks JT 
(1998): Prolonged recovery in first-episode psychosis. $\mathrm{Br} \mathrm{J}$ Psychiatry Suppl 172:107-116.

Emsley RA (1999): Risperidone in the treatment of first-episode psychotic patients: A double-blind multicenter study. Risperidone Working Group. Schizophr Bull 25:721-729.

Erlenmeyer-Kimling L, Cornblatt B (1987): High-risk research in schizophrenia: A summary of what has been learned. J Psychiatr Res 21:401-411.

Fish B (1977): Neurobiologic antecedents of schizophrenia in children. Evidence for an inherited, congenital neurointegrative defect. Arch Gen Psychiatry 34:1297-1313.

Fukuzako H, Takeuchi K, Hokazono Y, Fukuzako T, Yamada K, Hashiguchi T, et al (1995): Proton magnetic resonance spectroscopy of the left medial temporal and frontal lobes in chronic schizophrenia: Preliminary report. Psychiatry Res 61:193-200.

Garver DL, Nair TR, Christensen JD (1997): 'Schizophrenia as a chronic active brain process ... ': Perhaps, but only in part [letter; comment]. Psychiatry Res 76:131-138.

Gilmore JH, van Tol JJ, Streicher HL, Williamson K, Cohen SB, Greenwood RS, et al (2000): Outcome in children with fetal mild ventriculomegaly: A case series. Schizophr Res, in press.

Goldberg TE, Gold JM (1995): Neurocognitive deficits in schizophrenia. In: Hirsch SR, Weinberger D, editors. Schizophrenia. Oxford: Oxford Press, 146-162.

Gottesman II (1991): Schizophrenia: The Origins of Madness. New York: Freeman.

Gottesman II, Erlenmeyer-Kimling L (2001): Family and twin strategies as a head start in defining prodromes and endophenotypes for hypothetical early-interventions in schizophrenia. Schizophr Res 51:93-102.

Gur RE, Cowell P, Turetsky BI, Gallacher F, Cannon T, Bilker W, et al (1998): A follow-up magnetic resonance imaging study of schizophrenia. Relationship of neuroanatomical changes to clinical and neurobehavioral measures. Arch Gen Psychiatry 55:145-152.

Haas GL, Garratt LS, Sweeney JA (1998): Delay to first antipsychotic medication in schizophrenia: Impact on symptomatology and clinical course of illness. $J$ Psychiatr Res 32:151-159.

Hafner H, ad der Heiden W, Behrens S, Gattaz WF, Hambrecht M, Loffler W, et al (1998): Causes and consequences of the gender difference in age at onset of schizophrenia. Schizophr Bull 24:99-113.

Harrigan S, McGorry P, Krstev H, Early Psychosis Prevention and Intervention Centre, The Universiy of Melbourne, Australia (): Does treatment delay in firt-episode psychosis really matter? Available at: http://www.eppic.org.au. Accessed October 20, 2001.

Harvey PD, Silverman JM, Mohs RC, Parrella M, White L, Powchik P, et al (1999): Cognitive decline in late-life schizophrenia: A longitudinal study of geriatric chronically hospitalized patients. Biol Psychiatry 45:32-40.

Hegarty JD, Baldessarini RJ, Tohen M, Waternaux C, Oepen G (1994): One hundred years of schizophrenia: A meta-analysis of the outcome literature. Am J Psychiatry 151:1409-1416.

Ho BC, Andreasen NC, Flaum M, Nopoulos P, Miller D (2000): Untreated initial psychosis: Its relation to quality of life and symptom remission in first-episode schizophrenia. Am J Psychiatry 157:808-815.
Hoff AL, Sakuma M, Razi K, Heydebrand G, Csernansky JG, DeLisi LE (2000): Lack of association between duration of untreated illness and severity of cognitive and structural brain deficits at the first episode of schizophrenia. Am J Psychiatry 157:1824-1828.

Jablensky A, Sartorius N, Ernberg G, Anker M, Korten A, Cooper JE, et al (1992): Schizophrenia: Manifestations, incidence and course in different cultures. A World Health Organization ten-country study. Psychol Med Monogr Suppl 20:1-97.

Jarskog LF, Gilmore JH, Selinger ES, Lieberman JA (2000): Cortical bcl-2 protein expression and apoptotic regulation in schizophrenia. Biol Psychiatry 48:641-650.

Jody D, Lieberman JA, Geisler S, Szymanski S, Alvir JMJ (1990): Behavioral response to methylphenidate and treatment outcome in first episode schizophrenia. Psychopharmacol Bull 26:297-301.

Jones P (1997): The early origins of schizophrenia. Br Med Bull:135-155.

Keshavan MS, Bagwell WW, Haas GL, Sweeney JA, Schooler NR, Pettegrew JW (1994): Changes in caudate volume with neuroleptic treatment. Lancet 344:1434.

Keshavan MS, Stanley JA, Pettegrew JW (2000): Magnetic resonance spectroscopy in schizophrenia: Methodological issues and findings-part II. Biol Psychiatry 48:369-380.

Kraepelin E (1919): Dementia Praecox and Paraphrenia. Edinburgh, Scotland: Livingstone.

Larsen TK, Moe LC, Vibe-Hansen L, Johannessen J (2000): Premorbid functioning versus duration of untreated psychosis in 1 year outcome in first-episode psychosis. Schizophr Res 75:1-9.

Larsen TK, Johannessen JO, Opjordsmoen S (1998): Firstepisode schizophrenia with long duration of untreated psychosis. Pathways to care. Br J Psychiatry 172(suppl 33):4552.

Laruelle M, Abi-Dargham A, Gil R, Kegeles L, Innis R (1999): Increased dopamine transmission in schizophrenia: Relationship to illness phases. Biol Psychiatry 46:56-72.

Lewis DA, Lieberman JA (2000): Catching up on schizophrenia: Natural history and neurobiology. Neuron 28:325-334.

Lieberman JA (1999b): Is schizophrenia a neurodegenerative disorder? A clinical and neurobiological perspective Biol Psychiatry 46:729-739.

Lieberman JA, Alvir JM, Koreen A, Geisler S, Chakos M, Sheitman B, et al (1996): Psychobiologic correlates of treatment response in schizophrenia. Neuropsychopharmacology 14:13S-21S.

Lieberman J, Bogerts B, Degreef G, Ashtari M, Lantos G, Alvir J (1992): Qualitative assessment of brain morphology in acute and chronic schizophrenia. Am J Psychiatry 149:784-794.

Lieberman J, Chakos M, Wu H, Alvir J, Hoffman E, Robinson D, et al (2001): Longitudinal study of brain morphology in first episode schizophrenia. Biol Psychiatry 49:487-499.

Lieberman JA, Fenton W (2000): Delayed detection of psychosis: Causes, consequences, and effect on public health. Am J Psychiatry, 157:1727-1730.

Lieberman J, Jody D, Geisler S, Alvir J, Loebel A, Szymanski S, et al (1993): Time course and biologic correlates of treatment response in first-episode schizophrenia. Arch Gen Psychiatry 50:369-376. 
Lieberman JA, Sheitman BB, Kinon BJ (1997): Neurochemical sensitization in the pathophysiology of schizophrenia: Deficits and dysfunction in neuronal regulation and plasticity. Neuropsychopharmacology 17:205-229.

Linszen DH, Dingemans PM, Lenior ME, Scholte WF, De Haan L, Goldstein MJ (1998): Early detection and intervention in schizophrenia. Int Clin Psychopharmacol 13(suppl 3):S31S34.

Loebel A, Lieberman JA, Alvir JMJ, Mayerhoff D, Geisler S, Szymanski S (1992): Duration of psychosis and outcome in first-episode schizophrenia. Am J Psychiatry 149:1183-1188.

Madsen AL, Karle A, Rubin P, Cortsen M, Andersen HS, Hemmingsen R (1999): Progressive atrophy of the frontal lobes in first-episode schizophrenia: Interaction with clinical course and neuroleptic treatment. Acta Psychiatr Scand 100: 367-374.

Maier M, Ron MA, Barker GJ, Tofts PS (1995): Proton magnetic resonance spectroscopy: An in vivo method of estimating hippocampal neuronal depletion in schizophrenia [published erratum appears in Psychol Med 1996 Jul;26(4):877]. Psychol Med 25:1201-1209.

Mathalon DH, Sullivan EV, Lim KO, Pfefferbaum A (2001): Progressive brain volume changes and the clinical course of schizophrenia in men: A longitudinal magnetic resonance imaging study. Arch Gen Psychiatry 58:148-157.

McEvoy J, Lieberman J, Tohen M, Sanger T, Keefe R, Charles $\mathrm{H}$, et al (2000): Olanzapine versus haloperidol in the treatment of first-episode psychosis. Abstract presented at the 39th Annual American College of Neuropsychopharmacology 39th Annual Meeting San Juan Puerto Rico December 10-14, 2000. (ACNP)

McGlashan TH (1988): A selective review of recent North American long-term followup studies of schizophrenia. Schizophr Bull 14:515-542.

McGlashan TH (1996): Early detection and intervention in schizophrenia: Research. Schizophr Bull 22:327-345.

McGlashan TH (1999): Duration of untreated psychosis in first-episode schizophrenia: Marker or determinant of course? [see comments] [published erratum appears in Biol Psychiatry 2000 Mar 1:47(5):473]. Biol Psychiatry 46:899-907.

McGorry P, Yung A, Phillips L (1999): People at risk of schizophrenia and other psychoses: Comments on the Edinburgh High-Risk Study. Br J Psychiatry 175:586-587.

McGorry PD, Edwards J, Mihalopoulos C, Harrigan SM, Jackson HJ (1996b): EPPIC: An evolving system of early detection and optimal management. Schizophr Bull 22:305-326.

Mohn AR, Gainetdinov RR, Caron MG, Koller BH (1999): Mice with reduced NMDA receptor expression display behaviors related to schizophrenia. Cell 98:427-436.

Murray RM, Lewis SW (1987): Is schizophrenia a neurodevelopmental disorder? BMJ 295:681-682.

Nair, TR, Christensen, JD, Kingsbury, SJ, Kumar, NG, Terry, WM, Garver, DL (1997): Progression of cerebroventricular enlargement and the subtyping of schizophrenia. Psychiatry Res 74:141-150.

Nasrallah HA, Skinner TE, Schmalbrock P, Robitaille PM (1994): Proton magnetic resonance spectroscopy (1H MRS) of the hippocampal formation in schizophrenia: A pilot study. Br J Psychiatry 165:481-485.
Nuechterlein KH, Dawson ME (1984): Information processing and attentional functioning in the developmental course of schizophrenic disorders. Schizophr Bull 10:160-203.

Nuechterlein KH, Dawson ME, Green MF (1994): Informationprocessing abnormalities as neuropsychological vulnerability indicators for schizophrenia. Acta Psychiatr Scand Suppl 384:71-79.

Olney JW, Farber NB (1995): Glutamate receptor dysfunction and schizophrenia. Arch Gen Psychiatry 52:998-1007.

Pert A, Post R, Weiss SRB (1992): Conditioning a critical determinantof sensitization induced by psychomotor stimulants. In: Erinoff L, editor. Neurobiology of Drug Abuse: Learning and Memory, Rockville, MD: US Dept. of Health and Human Services, National Institute on Drug Abuse; Washington, DC: 208.

Pettegrew JA, Keshavan JS, Panchalingam K, Strychor S, Kaplan DB, Tretta MG (1991): Alterationsin brain highenergy phosphate and membrane phospholipid metabolism in first episode drug naive, schizophrenics. Arch Gen Psychiatry 48:563-568.

Posner MI, Early TS, Reiman E, Pardo PJ, Dhawan M (1988): Asymmetries in hemispheric control of attention in schizophrenia [see comments]. Arch Gen Psychiatry 45:814-821.

Rapoport JL, Giedd JN, Blumenthal J, Hamburger S, Jeffries N, Fernandez T, et al (1999): Progressive cortical change during adolescence in childhood-onset schizophrenia. A longitudinal magnetic resonance imaging study. Arch Gen Psychiatry 56:649-654.

Renshaw PF, Yurgelun-Todd DA, Tohen M, Gruber S, Cohen BM (1995): Temporal lobe proton magnetic resonance spectroscopy of patients with first-episode psychosis. Am J Psychiatry 152:444-446.

Robinson D, Woerner M, Alvir J, Bilder RM, Goldman R, Geisler S, et al (1999a): Predictors of treatment response from a first episode of schizophrenia or schizoaffective disorder. Am J Psychiatry 156:544-549.

Robinson D, Woerner MG, Alvir JM, Bilder R, Goldman R, Geisler S, Koreen A, Sheitman B, Chakos M, Mayerhoff D, Lieberman JA (1996b): Predictors of relapse following response from a first episode of schizophrenia or schizoaffective disorder. Arch Gen Psychiatry 56:241-247.

Schaffner KF, McGorry PD (2001): Preventing severe mental illnesses-new prospects and ethical challenges. Schizophr Res 51:3-15.

Scully PJ, Coakley G, Kinsella A, Waddington JL (1997): Psychopathology, executive (frontal) and general cognitive impairment in relation to duration of initially untreated versus subsequently treated psychosis in chronic schizophrenia. Psychol Med 27:1303-1310.

Shioiri T, Hamakawa H, Kato T, Murashita J, Fujii K, Inubushi T, et al (1996): Proton magnetic resonance spectroscopy of the basal ganglia in patients with schizophrenia: A preliminary report. Schizophr Res 22:19-26.

Siegel C, Waldo M, Mizner G, Adler LE, Freedman R (1984): Deficits in sensory gating in schizophrenic patients and their relatives. Evidence obtained with auditory evoked responses. Arch Gen Psychiatry 41:607-612.

Stanley JA, Drost DJ, Williamson PC, Thompson RT (1995a): The use of a priori knowledge to quantify short echo in vivo 1H MR spectra. Magn Reson Med 34:17-24. 
Stanley JA, Williamson PC, Drost DJ, Carr TJ, Rylett RJ, Malla A, et al (1995b): An in vivo study of the prefrontal cortex of schizophrenic patients at different stages of illness via phosphorus magnetic resonance spectroscopy. Arch Gen Psychiatry 52:399-406.

Stanley JA, Williamson PC, Drost DJ, Rylett RJ, Carr TJ, Malla A, et al (1996): An in vivo proton magnetic resonance spectroscopy study of schizophrenia patients. Schizophr Bull 22:597-609.

Szymanski SR, Cannon TD, Gallacher F, Erwin RJ, Gur RE (1996): Course of treatment response in first-episode and chronic schizophrenia. Am J Psychiatry 153:519-525.

Verdoux H, Liraud F, Bergey C, Assens F, Abalan F, Van Os J (2001): Is the association between duration of untreated psychosis and outcome confounded? A two year follow-up study of first-admitted patients. Schizophr Res 49:231-241.

Vion-Dury J, Nicoli F, Salvan AM, Confort-Gouny S, Dhiver C, Cozzone PJ (1995): Reversal of brain metabolic alterations with zidovudine detected by proton localised magnetic resonance spectroscopy [letter]. Lancet 345:60-61.

Waddington JL, Lane A, Larkin C, O'Callaghan E (1999): The neurodevelopmental basis of schizophrenia: Clinical clues from cerebro-craniofacial dysmorphogenesis, and the roots of a lifetime trajectory of disease. Biol Psychiatry 46:31-39.

Waddington JL, Youssef HA, Kinsella A (1995): Sequential crosssectional and 10-year prospective study of severe negative symptoms in relation to duration of initially untreated psychosis in chronic schizophrenia. Psychol Med 25:849-857.

Waldo MC, Carey G, Myles-Worsley M, Cawthra E, Adler LE, Nagamoto HT, et al (1991): Codistribution of a sensory gating deficit and schizophrenia in multi-affected families. Psychiatry Res 39:257-268.

Walker E, Lewine RJ (1990): Prediction of adult-onset schizophrenia from childhood home movies of the patients. Am J Psychiatry 147:1052-1056.
Wang B, Gonzalo-Ruiz A, Morte L, Campbell G, Lieberman AR (1999): Immunoelectron microscopic study of glutamate inputs from the retrosplenial granular cortex to identified thalamocortical projection neurons in the anterior thalamus of the rat. Brain Res Bull 50:63-76.

Weinberger DR (1987): Implications of normal brain development for the pathogenesis of schizophrenia. Arch Gen Psychiatry 44:660-669.

Weiss F, Paulus MP, Lorang MT, Koob GF (1992): Increases in extracellular dopamine in the nucleus accumbens by cocaine are inversely related to basal levels: Effects of acute and repeated administration. J Neurosci 12:4372-4380.

Whitesides J, Hall M, Anchan R, LaMantia AS (1998): Retinoid signaling distinguishes a subpopulation of olfactory receptor neurons in the developing and adult mouse. J Comp Neurol 394:445-461.

Whooley MA, Avins AL, Miranda J, Browner WS (1997): Case-finding instruments for depression. Two questions are as good as many [see comments]. J Gen Intern Med 12:439445 .

Wyatt RJ (1991): Early intervention with neuroleptics may decrease the long-term morbidity of schizophrenia. Schizophr Res 5:201-202.

Wyatt RJ (1995): Early intervention for schizophrenia: Can the course of the illness be altered? Biol Psychiatry 38:1-3.

Wyatt RJ, Green MF, Tuma AH (1997): Long-term morbidity associated with delayed treatment of first admission schizophrenic patients: A re-analysis of the Camarillo State Hospital data. Psychol Med 27:261-268.

Yurgelun-Todd DA, Waternaux CM, Cohen BM, Gruber SA, English CD, Renshaw PF (1996): Functional magnetic resonance imaging of schizophrenic patients and comparison subjects during word production. Am J Psychiatry 153:200205. 